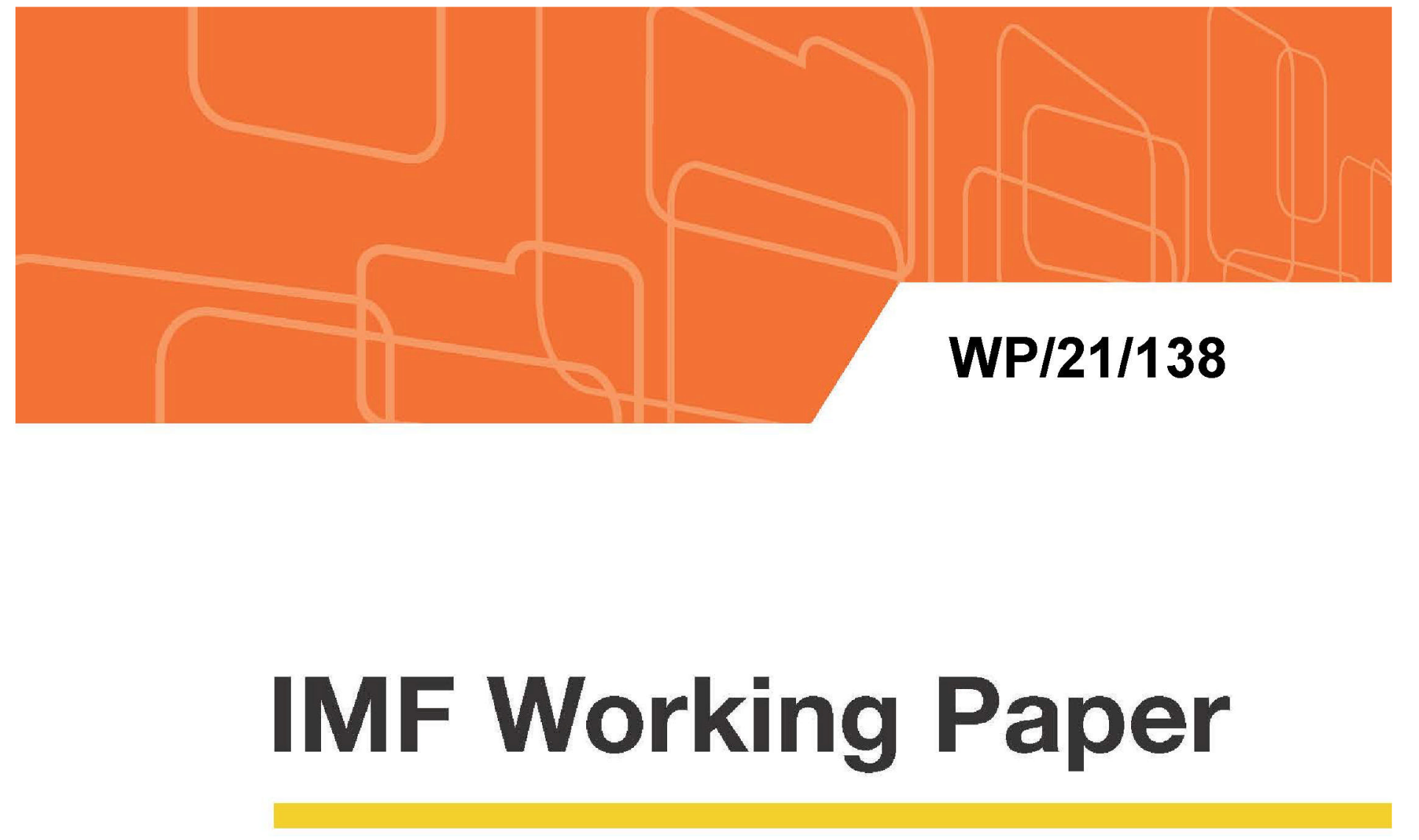

\title{
China's Rebalancing and Gender Inequality
}

by Mariya Brussevich, Era Dabla-Norris, and Bin Grace Li

IMF Working Papers describe research in progress by the author(s) and are published to elicit comments and to encourage debate. The views expressed in IMF Working Papers are those of the author(s) and do not necessarily represent the views of the IMF, its Executive Board, or IMF management. 


\title{
IMF Working Paper
}

Asia and Pacific Department

\section{China's Rebalancing and Gender Inequality}

\section{Prepared by Mariya Brussevich, Era Dabla-Norris, and Bin Grace Li ${ }^{1}$}

Authorized for distribution by Era Dabla-Norris

May 2021

\section{IMF Working Papers describe research in progress by the author(s) and are published to elicit comments and to encourage debate. The views expressed in IMF Working Papers are those of the author(s) and do not necessarily represent the views of the IMF, its Executive Board, or IMF management.}

\begin{abstract}
This paper examines gender inequality in the context of structural transformation and rebalancing in China. We document declining women's relative wages and labor force participation in China during the last two decades, despite rapid growth and expansion of the service sector. Using household data, we provide evidence consistent with a U-shaped relationship between economic development and women's labor market outcomes. Using a model of structural transformation, we show that labor market barriers for women have increased over time. Model counterfactuals suggest that removing these barriers and increasing service sector productivity can boost both gender equality and economic growth in China.
\end{abstract}

JEL Classification Numbers: D3, E24, E62, J16, J22

Keywords: gender inequality, structural transformation, household data, labor force participation

Author's E-Mail Addresses: mbrussevich@imf.org, edablanorris@imf.org, bli2@imf.org.

\footnotetext{
${ }^{1}$ We are grateful to the IMF China Team, Sandra Valentina Lizarazo Ruiz, Marina Mendes Tavares, SEA Conference (Washington DC, 2018) and IMF seminar participants for their comments. Hibah Khan, Joey Kilpatrick, and Jay Rappaport provided excellent research assistance.
} 


\section{Introduction}

The saying "Women hold up half the sky" is a well-known adage about the role of women in China since the 1960s. Generations of Chinese men and women have grown up with the idea of gender equality, which has contributed to the country's strong female workforce. However, China's rapid economic development and unprecedented growth has also been accompanied by widening gender gaps. The gender gap in labor force participation (LFP) between men and women nearly doubled over the last two decades, rising from 9 percentage points in the 1990s to almost 15 percentage points in 2020. The increase in gender earnings gap is even more pronounced. While many countries have moved closer to parity, China now ranks 106th in the global gender gap rankings among 153 countries slipping from 63rd position in 2006, according to the World Economic Forum (2019) report.

The COVID-19 pandemic is bringing these issues to the fore in light of its disproportionate impact on women and their employment opportunities in China and elsewhere (Alon, Doepke, Slmstead-Rumsey, and Tertilt, 2020; Dang and Nguyen, 2021; Bluedorn, Caselli, Hansen, Shibata, and Tavares, 2021). Existing gender gaps are likely to widen due to the elevated risk of job losses in affected sectors and the significantly higher family and childcare burden faced by women. China has framed its recovery policies to be more inclusive and balanced, presenting an opportunity to decisively tackle gender gaps in labor markets. ${ }^{1}$

In this paper we shed light on China's rebalancing from a gender perspective. Economic development and structural transformation have been associated with an increasing market share of the service sector in recent decades. The service sector has become the most important part of the economy in terms of employment and value added. We document that this shift to a services-based economy has been accompanied by widening gender gaps, a stylized fact that is at odds with the prediction of standard structural transformation models (Ngai and Petrongolo, 2017). Theory in fact suggests that structural change should be associated with higher female labor force participation (FLFP) as women reveal a comparative advantage in services - as also seen in cross-country empirical evidence (Olivetti, 2013; Rendall, 2018).

We first use micro-level data for the period 1995-2013 to examine the drivers of widening gender gaps in China. One important factor can be the income effect, in particular, the U-shaped relationship between FLFP rate and income growth found in the empirical literature. Using province-level data for China, we also find a negative correlation between GDP per capita and FLFP rates, with wealthier provinces exhibiting lower FLFP rates. We then estimate women's labor supply elasticity both to own wages and to spouse's wages using household data. We find that changes in labor supply by married women have driven aggregate gender wage inequality over the past 30 years. This is a consequence of their higher estimated labor supply elasticity to spouse's wages. We also find that presence of a child in the household had little impact on female labor supply in 1995. However, by 2013, the effect of the presence of a child in the household on women's labor hours is

\footnotetext{
${ }^{1}$ See President Xi Jinping's recent statement (link).
} 
negative and statistically significant, suggesting that women are more likely to reduce work hours after having a child.

As a second step, we take our empirical evidence to theory. We adapt a structural transformation model to examine the economic impacts of removing labor market participation barriers and speeding up marketization of home-produced services (e.g., child and elderly care, cleaning, food preparation). The latter is increasingly pertinent as service sector productivity growth in China has slowed in recent decades (Zhu, Zhang, and Peng, 2019). ${ }^{2}$ These two factors are critical determinants of aggregate output growth and gender gaps in an economy. Despite some progress in reducing the barriers women face in job advancement and wage parity, discrimination in these areas persists. Barriers emanate from labor market regulations (e.g., discriminatory hiring, firing and promotion practices, see Zhang and Huang (2020)), employer discrimination, and lack of affordable child and elderly care options. In the counterfactual analysis, we show that reducing barriers to the level observed in an advanced economy can narrow gender wage and LFP gaps by 5 and 15 percentage points, respectively. Similarly, accelerating marketization of services by increasing productivity of the market service sector (e.g., removing credit and labor market frictions, see Nabar and Yan (2013), and making it easier for women to achieve greater work-life balance) can narrow gender wage and LFP gaps, boosting aggregate output by 4.9 percent over the long run. ${ }^{3}$

This paper is organized as follows. Section 2 reviews the related literature. In Section 3, we document stylized facts on structural transformation and gender inequality in China, and use micro data to estimate changes in female labor supply elasticities over time. In Section 4, we lay out a theoretical model linking the stylized facts. Section 5 discusses a set of policies targeted at narrowing gender inequality and quantifies their effects on gender wage and employment gaps. Section 6 concludes.

\section{Related Literature}

Our study is related to three strands of literature. First, we contribute to the literature linking structural transformation to gender inequality in labor markets. A growing number of studies document a positive relationship between a rising service sector share and women's relative wages and employment, predominantly in advanced economies (Akbulut, 2011; Ngai and Petrongolo, 2017; Rendall, 2018). Similar trends have also been documented in developing countries by Rendall (2013) and Ostry, Alvarez, Espinoza, and Papageorgiou (2018). However, there are no systematic studies linking structural transformation and gender inequality in China. We fill this gap in the literature by documenting key facts on structural transformation and gender inequality and calibrate a model of structural transformation for the case of China. Consistent with the literature on the existence of a U-shaped relationship between economic growth and female labor force participation (Goldin,

\footnotetext{
${ }^{2}$ Labor productivity growth in the service sector is not just significantly lower than in manufacturing, it has also slowed substantially since the Global Financial Crisis (Zhu, Zhang, and Peng, 2019). Similarly, TFP growth in the service sector has shown a declining trend since early 2000.

${ }^{3}$ Rapid population aging — one of the legacies of China's one-child policy — is likely to exacerbate gender inequality, as the burden of elderly care is likely to disproportionately fall on women.
} 
1994), we find that gender inequality in China has widened despite rapid economic growth and rising service sector share.

This study also contributes to the literature estimating female labor supply elasticities and the role of cultural norms in women's decision to participate in the labor market (Blau and Kahn, 2007; Heim, 2007; Chen and Ge, 2018). Unlike Blau and Kahn (2007) and Heim (2007), who document a sizable decrease in women's labor supply elasticities to both own and spouse's wages in the US associated with a cultural shift in the household roles, we find evidence of a reverse trend unfolding in China. Our study is the first to systematically document the shift in female labor supply elasticities in China using micro data. ${ }^{4}$

Finally, our study is related to the growing literature examining the link between economic growth, globalization and income inequality in China. Han, Liu, and Zhang (2012) and Li, Loungani, and Ostry (2017) find that income inequality has widened following China's accession to the World Trade Organization (WTO), concluding that gains from economic growth have not been distributed equally across the Chinese population. Dong and Joffre (2019), Liu, Li, and Yang (2014), and Dasgupta, Matsumoto, and Xia (2015) also document worsening gender disparities in employment and income in China in recent decades. We contribute to this literature by analyzing the drivers of rising gender inequality in China from both macro and micro perspectives and using a theoretical framework of structural transformation to quantify the gains from appropriate policies.

\section{Structural Transformation and Gender Gaps in China}

This section outlines a set of stylized facts on gender wage and employment gaps in China as well as patterns of structural transformation over the past two decades - the period characterized by unprecedented economic growth in China. Using existing predictions of the structural transformation theory, we identify anomalies in the relationship between gender inequality and growth of the service sector in China. We then turn to micro data to estimate female labor supply elasticities.

\subsection{Stylized Facts and Anomalies}

\section{Fact 1: Declining LFP and Widening Gender LFP Gap}

Figure 1 presents evidence of widening LFP gap between men and women in China. In the figure, we show gender LFP rates for the population aged 15 or older from the International Labour Organization (ILO) between 2000 and 2019. This period is characterized by rapid economic expansion following a series of privatization and other market-oriented reforms implemented in China since the 1990s. During this period, LFP rates of both men and women decline, following a series of state-owned enterprises reforms which resulted in mass layoffs (Feng, Hu, and Moffitt, 2017). However, the impact of these reforms on female employment has been more dramatic, with

\footnotetext{
${ }^{4} \mathrm{Li}$ and Zax (2003) is the only study to our knowledge estimating labor supply elasticities for male and female workers in 1995. However, their study does not document changes in elasticities over time and does not estimate women's labor supply elasticities to spouse's wages.
} 
Figure 1: Labor Force Participation Rate by Gender (2000-2019)

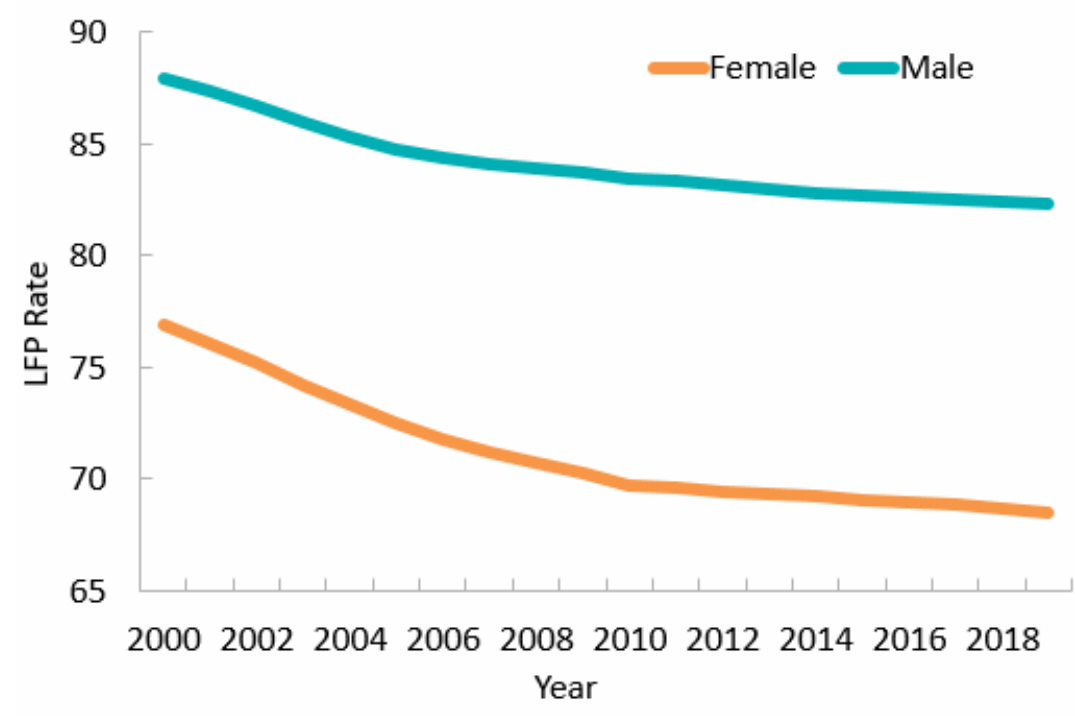

Source: ILO and staff calculations.

FLFP declining significantly faster, especially after 2010. As a result, the already sizable gender LFP gap of about 11 percentage points in 2000, widened to about 14 percentage points by 2013 and remained at that level. It is important to note that the LFP gap in Figure 1 does not account for gender-specific changes in average work hours. As shown below, women have also witnessed a decline in their average paid work hours compared to men, which has further contributed to rising gender inequality in the labor market. In contrast to the trends documented in China, this period can be characterized by falling gender inequality around the world and particularly in other emerging market economies.

\section{Fact 2: Widening Gender Wage Gap}

We use micro data on household hours, wages, and other individual characteristics from the Chinese Household Income Project (CHIP) survey to examine gender wage gaps. ${ }^{5}$ We compare outcomes from two waves of the CHIP survey - 1995 and 2013 - before and after large-scale marketoriented reforms and China's entry into the WTO. The sample is limited to the working-age population (between 15 and 64 years) with non-zero wage incomes.

We estimate a conditional gender wage gap as follows:

$$
\log \left(w_{i}\right)=\alpha^{g}+\beta_{1}^{g} \text { Female }_{i}+\beta_{2}^{g} X_{i}^{g}+\epsilon_{i}^{g},
$$

where $\log \left(w_{i}\right)$ is a real annual log wage or salary of individual $i$ and vector $X_{i}^{g}$ contains personal characteristics including age, age squared, presence of child in the household, marital status, level

\footnotetext{
${ }^{5}$ CHIP surveys were intended to document income distribution across urban and rural areas in China. The survey was conducted in 1988, 1995, 2002, 2007, and 2013 with assistance of China's National Bureau of Statistics.
} 
of educational attainment, residence in urban or rural area, and sector of employment. We estimate this regression separately for the 1995 and 2013 samples using province population weights in both regressions. The coefficient on the female binary variable indicates the size of the gender wage gap.

Table 1 contains the results of the gender wage gap regression. Controlling for demographics, levels of educational attainment, and sectoral composition, we find a significant increase in the gender wage gap from 12 percent in 1995 to 35 percent in 2013.

Table 1: Widening Gender Earnings Gap

\begin{tabular}{lcc}
\hline & 1995 sample & 2013 sample \\
\hline Female & $-0.119^{* * *}$ & $-0.351^{* * *}$ \\
Age & $(0.017)$ & $(0.021)$ \\
& $0.056^{* * *}$ & $0.078^{* * *}$ \\
$(\text { Age })^{2}$ & $(0.014)$ & $(0.006)$ \\
& $-0.001^{* * *}$ & $-0.001^{* * *}$ \\
Child in HH & $(0.000)$ & $(0.000)$ \\
& $-0.060^{*}$ & $-0.081^{* * *}$ \\
Married & $(0.034)$ & $(0.020)$ \\
& 0.044 & $0.095^{* *}$ \\
Education & $(0.071)$ & $(0.034)$ \\
High School & & \\
& $0.127^{* * *}$ & $0.171^{* * *}$ \\
College & $(0.021)$ & $(0.021)$ \\
& $0.402^{* * *}$ & $0.570^{* * *}$ \\
Voc. Training & $(0.026)$ & $(0.043)$ \\
& $0.280^{* * *}$ & $0.284^{* * *}$ \\
Urban & $(0.016)$ & $(0.032)$ \\
& 0.042 & $0.223^{* * *}$ \\
Service sector & $(0.099)$ & $(0.030)$ \\
& $0.059^{* *}$ & -0.011 \\
Constant & $(0.026)$ & $(0.021)$ \\
& $7.197^{* * *}$ & $8.723^{* * *}$ \\
Observations & $(0.285)$ & $(0.112)$ \\
R-squared & 13,015 & 40,620 \\
\hline
\end{tabular}

Notes: The dependent variable is real annual log wages. Robust standard errors are in parentheses. Omitted category in education attainment levels is "Less than High School." Omitted category in sector is goods sector.

${ }^{* * *} \mathrm{p}<0.01,{ }^{* *} \mathrm{p}<0.05,{ }^{*} \mathrm{p}<0.1$

Source: CHIP and staff calculations.

\section{Fact 3: Rising Service Sector Share}

We use sectoral employment data by gender from the ILO to examine the patterns of structural transformation in China between 2000 and 2019. We focus on two broad sectors: goods and service sectors. Goods sector includes agriculture, mining, construction, utilities, and manufacturing sectors, while service sector includes all other activities, like wholesale and retail, transportation, 
finance, health, education, etc. ${ }^{6}$ Figure 2 plots female and male employment shares in both sectors over time.

Figure 2: Sectoral Employment Shares by Gender (2010-2019)
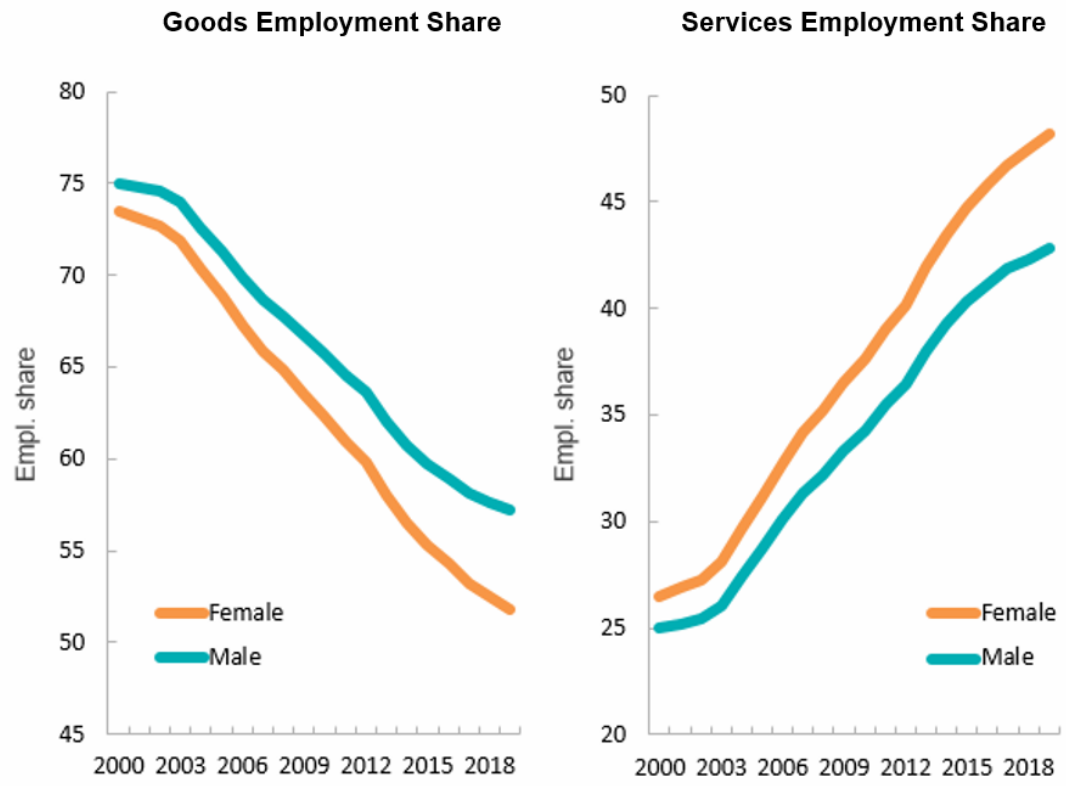

Source: ILO and staff calculations.

First, Figure 2 suggests that higher concentration of female workers in the service sector is associated with women's revealed comparative advantage in services while men's revealed comparative advantage is in the goods sector. Second, declining goods sector share and rising services share are consistent with the structural transformation patterns observed in other advanced and emerging market economies (Herrendorf, Rogerson, and Valentinyi, 2014). Reallocation of female labor from goods to services has been more rapid: female (male) employment share in the goods sector decreased from 73 (75) percent in 1995 to 52 (57) percent in 2019.

\section{Puzzle: Structural Transformation and Widening Gender Inequality in China}

Structural transformation patterns in China over the last two decades are consistent with the experiences of other advanced and emerging market economies. However, there is a disconnect between these structural transformation trends and widening gender inequality specific to the case of China. Akbulut (2011), Ngai and Petrongolo (2017), and Rendall (2018) document evidence suggesting that growth of the service sector in the process of structural transformation is associated with a decrease in gender inequality both in hours worked and wages in the US, since women have a revealed comparative advantage in producing services. Similarly, Rendall (2013) documents evidence of narrowing gender gaps in response to the rise of the service sector in other emerging economies, including Brazil, India, Mexico, and Thailand.

\footnotetext{
${ }^{6}$ Similar patterns hold in the case where agricultural sector is separated from the goods sector.
} 
The evidence on sectoral employment shares and gender wage and hours gaps in China posits a puzzle from a point of view of the structural transformation literature that we examine in the remainder of the paper.

\subsection{Economic Growth and Female Labor Force Participation}

One strand of literature, first introduced by Sinha (1965), shows that an inverse relationship between economic growth and FLFP is plausible at certain stages of the country's economic development. A U-shaped relationship between economic growth and FLFP was analyzed by Goldin (1994), Mammen and Paxson (2000), Olivetti (2013), and Olivetti and Petrongolo (2016). At low levels of development, women intensively participate in economic production, particularly at home and in agriculture. As the industrial sector, where men reveal a comparative advantage, grows and incomes reach a level where returns to dual-earner households begin to diminish in terms of additional household consumption, women begin to exit the labor force. At higher levels of development, with increasing educational attainment and growing service sector, where women have a comparative advantage, there is an upswing in FLFP rates.

Figure 3: China: Female Employment and Province-Level Income

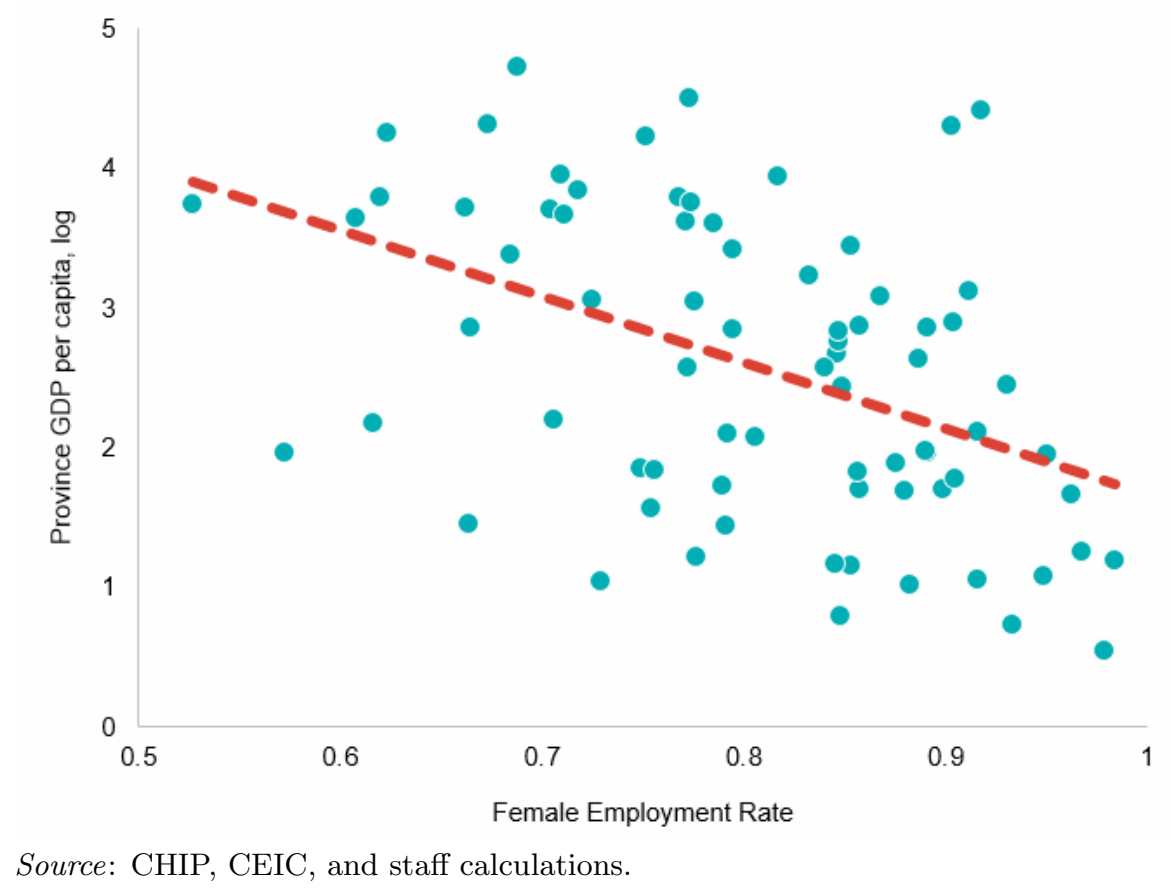

Along these lines, Jayachandran (2020) shows that gender norms mediate the relationship between economic growth and female labor supply and argues that a stigma attached to women working outside of the household is present at earlier stages of development. Income growth allows households to rely on a single male earner, allowing women to invest in child-rearing activities. Chen and Ge (2018) demonstrate that cultural norms play a significant role in FLFP in China. 
They show that men with non-working mothers are more averse to their wives' market work and are less likely to participate in home production.

To explore whether an inverse relationship between economic growth and FLFP holds in the case of China, we use province-level variation in output per capita and female employment shares between 1995 and 2013. Figure 3 indeed shows a clear negative correlation-richer provinces see substantially lower rates of female employment compared to their poorer counterparts. In the next section, we test this hypothesis by focusing on the shifts in labor supply elasticities of married women in China over time, using micro data.

\subsection{Female Labor Supply Elasticities: Evidence from Micro Data}

\section{Who Drives the Aggregate Changes?}

In this section, we take a closer look at the drivers of labor supply of women between 1995 and 2013. Following the literature studying changes in female labor supply, we first compare labor market outcomes of married and unmarried women (Blau and Kahn, 2007; Heim, 2007). Related empirical studies pay particular attention to the married women's labor supply as it does not only respond to own wages but also to spouse's wages and thus is more elastic.

To compare changes in earnings over time, we first re-estimate Equation 1 separately for married and unmarried individuals' annual log wages. Second, we estimate a similar specification, replacing annual wages with weekly $\log$ hours of work. The coefficient on the female indicator in Table 2 indicates the magnitude of the gender earnings or hours gap in 1995 and 2013 for married and unmarried individuals separately.

Table 2: Differences in Gender Hours and Earnings Gaps for Married and Unmarried Workers

\begin{tabular}{lcccc}
\hline & \multicolumn{2}{c}{ Gender } & Hours Gap & \multicolumn{2}{c}{ Gender } & Earnings Gap \\
& 1995 & 2013 & 1995 & 2013 \\
\hline Married & $-0.027^{* * *}$ & $-0.033^{*}$ & $-0.153^{* * *}$ & $-0.395^{* * *}$ \\
& $(0.007)$ & $(0.017)$ & $(0.022)$ & $(0.023)$ \\
Unmarried & -0.006 & $0.066^{* * *}$ & -0.024 & $-0.090^{* * *}$ \\
& $(0.012)$ & $(0.020)$ & $(0.036)$ & $(0.019)$ \\
\hline Rural & -0.027 & -0.024 & -0.073 & $-0.357^{* * *}$ \\
& $(0.023)$ & $(0.019)$ & $(0.064)$ & $(0.026)$ \\
Urban & $-0.019^{* * *}$ & $-0.053^{* * *}$ & $-0.142^{* * *}$ & $-0.314^{* * *}$ \\
& $(0.006)$ & $(0.008)$ & $(0.017)$ & $(0.020)$ \\
\hline
\end{tabular}

Notes: The dependent variable is log weekly work hours or log annual earnings. Coefficients on the female binary variable are reported. All regressions control for age, age squared, presence of children in the household, education level, and urban residence. Robust standard errors are in parentheses.

${ }^{* * *} \mathrm{p}<0.01,{ }^{* *} \mathrm{p}<0.05,{ }^{*} \mathrm{p}<0.1$

Source: CHIP and staff calculations.

We find that, between 1995 and 2013, hours gaps reversed for unmarried women, while earnings 
gaps slightly widened. In 1995, both coefficients for unmarried women are not statistically significant, indicating that gender differences in earnings and work hours for unmarried individuals were not statistically different from zero. In contrast, gender gaps for married workers have significantly widened over time, in line with the evidence in Table 1. These differences are both statistically and economically significant. Thus, changes in labor supply by married women have driven aggregate gender wage inequality over the past 30 years in China.

These results could be indicative of a motherhood penalty for married women. Our findings on the gender earnings and hours gaps in rural and urban areas further corroborate this hypothesis. While childcare provision may be limited in both rural and urban areas, women in rural areas can rely on grandparents' support - an option that is not available in urban areas especially for migrants. Table 1 demonstrates that the hours gap widened in urban areas and did not change in rural areas. This suggests that lack of childcare options potentially poses significant barriers to FLFP. Gender wage gaps are similar in rural and urban areas in 2013, indicating that mass migration from rural to urban areas further fueled gender inequality, in part due to scarcity of childcare alternatives in urban areas. Next, we take a closer look at the change in female labor supply elasticities to both own and spouse's wages and the changing impact of motherhood on FLFP during this period.

\section{Estimating Labor Supply Elasticities}

We evaluate changes in female labor supply behavior over time by estimating labor supply elasticities to own and spouse's wages. We use 1995 and 2013 CHIP surveys, limiting the sample to married women between ages of 15 and 64 residing in urban areas. ${ }^{7}$ We exclude students and individuals who are retired or disabled. All monetary variables used for estimation of labor supply elasticities are deflated using province-level CPI. Annual hours of work in 1995 are a product of average number of days per week, average hours per day, and the number of weeks worked, while annual hours of work in 2013 are a product of average number of work months per year, number of work day per month, and hours per day. The hourly wage variable is constructed using annual wage and salary income and annual hours of work. While this method of constructing hourly wages is commonly used in the literature, it is a well known that the resulting wage rate suffers from division bias. The measurement error in the hours variable is compounded in the hourly wage rates, which, in turn, leads to the attenuation bias in the labor supply elasticities as measurement error in wages ends up in the error term. We address this common issue using an instrumental variable approach explained below.

Our econometric model is based on Mroz (1987) and is similar to Heim (2007). The estimation procedure involves three steps. The first two steps follow the canonical Heckman selection correction method (Heckman, 1979). In the first step, we estimate a probit model for LFP for each year separately:

$$
p_{i}=\alpha^{p}+\beta_{1}^{p} \log \left(I_{i}\right)+\beta_{2}^{p} X_{i}^{p}+\epsilon_{i}^{p},
$$

\footnotetext{
${ }^{7}$ Information on the number of weekly work days needed to construct hourly wages is not available in the 1995 and 2013 rural surveys. Therefore, we only focus on the urban population in this section.
} 
where $p_{i}$ takes a value of one if work hours in a given year are positive and takes a value of zero otherwise. $\log \left(I_{i}\right)$ denotes household's non-labor income and $X_{i}^{p}$ includes individual characteristics contributing to the decision to participate in the labor force: age, age squared, education, presence of children in the household, as well as spouse's age, age squared, and education. ${ }^{8}$ We also control for county dummies and province population size. We compute the inverse Mills ratio from the probit estimates, which we use in the second stage:

$$
\lambda_{i}=\frac{\Phi\left(\hat{\alpha}^{p}+\hat{\beta}_{1}^{p} \log \left(I_{i}\right)+\hat{\beta}_{2}^{p} X_{i}^{p}\right)}{\phi\left(\hat{\alpha}^{p}+\hat{\beta}_{1}^{p} \log \left(I_{i}\right)+\hat{\beta}_{2}^{p} X_{i}^{p}\right)} .
$$

In the second stage, we run a selection-corrected wage regression:

$$
\log \left(w_{i}\right)=\alpha^{w}+\beta_{1}^{w} \lambda_{i}+\beta_{2}^{w} X_{i}^{w}+\epsilon_{i}^{w}
$$

where $\log \left(w_{i}\right)$ is $\log$ of female real wages and $X_{i}^{w}$ includes woman's and her spouse's age, age squared, education, as well as county dummies and province population. Based on the estimates from the second stage, we impute wages denoted by $\hat{w}_{i}$ for all individuals in our sample.

In the third stage, we estimate the labor supply elasticity, using imputed wages and inverse Mills ratio from the first two stages:

$$
h_{i}=\alpha^{h}+\beta_{1}^{h} \log \left(\hat{w}_{i}\right)+\beta_{2}^{h} \log \left(w_{i}^{s}\right)+\beta_{3}^{h} \log \left(I_{i}\right)+\beta_{4}^{h} \lambda_{i}+\beta_{5}^{h} X_{i}^{h}+\epsilon_{i}^{h} .
$$

$h_{i}$ denotes non-zero annual hours of work and $\log \left(w_{i}^{s}\right)$ denotes spouse's log hourly wages. We also include household non-labor income, $\log \left(I_{i}\right)$, and a set of individual and spouse's characteristics, denoted by $X_{i}^{h} . X_{i}^{h}$ includes woman's age, age squared, education, experience; spouse's age, age squared, education; presence of children in the household; province population and county dummies.

To address concerns related to endogeneity of wages when estimating Equation 2, we adopt an instrumental variable (IV) approach similar to Li and Zax (2003) and Blau and Kahn (2007). In addition to the division bias in wages mentioned above, unobserved individual characteristics such as the level of ability and motivation could be driving a positive correlation between hours of work and wages. To circumvent these issues, we instrument both own wages and spouse's wages with a set of individual- and local labor market-level variables similarly to Li and Zax (2003). At the individual level, we use a quadratic term of work experience as an instrument. At the local labor market level, we use a share of county employment in a public sector, which determines the local wage structure.

Table 3 contains OLS and IV regression results for female labor supply elasticity to own and spouse's wages in 1995 and 2013. We find a substantial increase in both women's own wage elasticities and spouse's wage elasticities. Unlike the case of the US where Blau and Kahn (2007) and

\footnotetext{
${ }^{8}$ We derive annual household non-labor income by summing total annual income across all household members and then subtracting annual labor income.
} 
Table 3: Labor Supply Estimates for Married Women

\begin{tabular}{lcccc}
\hline & \multicolumn{2}{c}{1995} & \multicolumn{2}{c}{2013} \\
& OLS & Three-Stage IV & OLS & Three-Stage IV \\
\hline $\log ($ Own Wage $)$ & $306.941^{* *}$ & 110.385 & $939.414^{* * *}$ & $699.724^{* * *}$ \\
& $(139.178)$ & $(167.927)$ & $(181.013)$ & $(172.555)$ \\
$\log ($ Spouse Wage $)$ & $-112.564^{* * *}$ & -161.875 & $-188.730^{* * *}$ & $-398.227^{* * *}$ \\
& $(13.397)$ & $(163.813)$ & $(19.120)$ & $(116.162)$ \\
$\log ($ Non-wage HH Income $)$ & -3.205 & -0.431 & $-7.087^{* * *}$ & $-18.532^{* * *}$ \\
& $(8.249)$ & $(9.647)$ & $(2.702)$ & $(4.215)$ \\
Child in HH & 3.211 & 25.908 & $-39.564^{*}$ & $-86.595^{* *}$ \\
& $(13.232)$ & $(30.647)$ & $(21.678)$ & $(34.640)$ \\
Observations & 3,768 & 3,768 & 5,604 & 5,604 \\
\hline Elasticities (at mean annual hours) & & & \\
Own Log Wage & 0.140 & 0.050 & 0.407 & 0.303 \\
Spouse Log Wage & -0.051 & -0.074 & -0.082 & -0.173 \\
\hline
\end{tabular}

Notes: The dependent variable is married women's annual hours of work. All models include inverse Mills ratio, education, age, experience, spouse's age and education, county dummies, province population, and a constant. Own imputed hourly log wages are instrumented with experience squared, and share of the public sector in a county. Spouse hourly log wages are instrumented with spouse's experience, experience squared, and share of the public sector in a county. The sample includes urban population only. Bootstrapped standard errors are in parentheses. ${ }^{* * *} \mathrm{p}<0.01,{ }^{* *} \mathrm{p}<0.05,{ }^{*} \mathrm{p}<0.1$

Source: CHIP and staff calculations.

Heim (2007) document declining own wage elasticities over time, consistent with a shift of female employment from "jobs" to "careers," we see the opposite trend in China. Between 1995 and 2013, women's labor supply became more responsive to wage offers on the market and spouse's wages, intensifying selection of women into the labor force. Specifically, own wage elasticity increased from 0.05 in 1995 to 0.3 in 2013 while spouse's wage elasticity declined from -0.07 to -0.17 .

We also find that presence of a child in the household had little impact on female labor supply in 1995, given that the coefficient on the child indicator is not statistically significant in Table 3. However, by 2013, the effect of the presence of a child in the household on women's labor hours becomes negative and statistically significant, suggesting that women are more likely to reduce work hours after having a child. These results suggest a possible shift to a one-earner household model from 1995 and 2013. Falling prevalence of a dual-earner household structure was driven by an unprecedented rise in incomes across China during this period, rendering female participation in the workforce a choice rather than a necessity, particularly in urban areas. ${ }^{9}$

\footnotetext{
${ }^{9}$ In addition, we tested the role of positive assortative matching, using the methodology in Greenwood, Guner, Kocharkov, and Santos (2014), where we regress women's years of education on spouse's years of education interacted with a 2013 dummy. We document a rise in assortative matching in China from 1995 and 2013 (results available upon request), suggesting the rising role of selection in widening gender wage and hours gaps.
} 


\section{Model of Structural Transformation}

We formalize the stylized facts outlined in Section 3 in a multi-sector model of structural transformation to identify the mechanisms that could be driving the observed increase in the gender gaps. We adapt the framework developed by Ngai and Petrongolo (2017) to the case of China. The model features female and male workers who allocate time to production in either of the two market sectors - goods and services - or a non-market home sector. ${ }^{10}$ Perfect labor mobility implies wage equalization across sectors for each gender. ${ }^{11}$

\section{Firms}

Goods sector denoted by $j=g$ and services denoted by $j=s$ are produced using the following technology:

$$
Y_{j}=A_{j} L_{j}, \quad L_{j}=\left[\xi_{j} L_{f j}^{\frac{\eta-1}{\eta}}+\left(1-\xi_{j}\right) L_{m j}^{\frac{\eta-1}{\eta}}\right]^{\frac{\eta}{\eta-1}},
$$

where two factors of production, $L_{f j}$ and $L_{m j}$, denote female and male labor, respectively. $\eta$ is an elasticity of substitution between female and male labor. Female labor has comparative advantage in the service sectors, implying that $\xi_{s}>\xi_{g}$. $A_{j}$ denotes labor productivity of sector $j$, growing at a rate $\frac{\dot{A}_{j}}{A_{j}} \equiv \gamma_{j}$. Productivity growth in the goods sector is faster than in the service sector, implying that $\gamma_{g}>\gamma_{s}$.

\section{Households}

Households consist of one man and one woman. Household utility depends on consumption of goods $\left(c_{g}\right)$, market-produced services $\left(c_{s}\right)$, and home-produced services $\left(c_{h}\right)$ :

$$
U\left(c_{g}, c_{s}, c_{h}\right)=\ln c
$$

where $c$ denotes a CES composite of goods and services:

$$
c=\left[\omega c_{g}^{\frac{\epsilon-1}{\epsilon}}+\omega c_{z}^{\frac{\epsilon-1}{\epsilon}}\right]^{\frac{\epsilon}{\epsilon-1}},
$$

and $c_{z}$ is a composite of market- and home-produced services:

$$
c_{z}=\left[\psi c_{s}^{\frac{\sigma-1}{\sigma}}+(1-\psi) c_{h}^{\frac{\sigma-1}{\sigma}}\right]^{\frac{\sigma}{\sigma-1}} .
$$

\footnotetext{
${ }^{10}$ Goods sector includes both agricultural and manufacturing industries. While there is churning within the goods sector. Namely, during the time period in question, manufacturing labor share increased and agricultural labor share shrank. Separating manufacturing and agricultural industries, however, does not provide alternative mechanisms helping to explain widening gender gaps, since both sectors are more male labor-intensive.

${ }^{11}$ This assumption is consistent with the 1995 and 2013 CHIP data on gender-specific wages in goods and service sectors. In addition, we find that year-specific gender wage gaps within sectors are almost identical.
} 
We impose $\epsilon<1$ and $\sigma>1$, implying that services and goods are complements in consumption while home- and market-produced services are substitutes in consumption. ${ }^{12}$

Home services are produced with the same technology as market services and services productivity grows faster in the market than in the home sector $\left(\gamma_{h}<\gamma_{s}\right)$ :

$$
c_{h}=A_{h}\left[\xi_{h} L_{f h}^{\frac{\eta-1}{\eta}}+\left(1-\xi_{h}\right) L_{m h}^{\frac{\eta-1}{\eta}}\right]^{\frac{\eta}{\eta-1}} .
$$

The presence of home-produced services in the CES preferences function implies non-homothetic utility in goods and market services and thus generates income effects.

Given market wages $\left(w_{f}, w_{m}\right)$ and market prices $\left(p_{g}, p_{s}\right)$, a representative household chooses market consumption and home production time to maximize utility subject to (5), (6), (7), and a household budget constraint:

$$
p_{g} c_{g}+p_{s} c_{s}=w_{m}\left(L_{m}-L_{m h}\right)+w_{f}\left(L_{f}-L_{f h}\right)
$$

\section{Equilibrium}

A competitive equilibrium is a collection of market wages, prices, consumption, and male and female time allocation across market sectors and home production such that (i) profits and household utility (4) are maximized, subject to (3) and (5)-(8), respectively; (ii) wages and sector prices clear the markets:

$$
c_{j}=Y_{j}, \quad j=g, s
$$

and (iii) male and female labor markets clear:

$$
L_{i g}+L_{i s}=L_{i}-L_{i h}, \quad i=f, m .
$$

\section{Productivity Wedges: Barriers to Female Labor Force Participation}

Barriers to FLFP are captured by the comparative advantage parameter $\xi_{j}$ in firm technology (Equation 3). Namely, the comparative advantage parameter is a function of "true" comparative advantage $\chi_{j}$ and a productivity wedge $\pi_{j}$ :

$$
\xi_{j}=\pi_{j} \chi_{j}, \quad j=g, s .
$$

Productivity wedges are assumed to reduce women's productivity in a given sector if $\pi_{j}<1$ and distort the equilibrium relationship between gender wage ratio and marginal rate of substitution of

\footnotetext{
${ }^{12}$ We do not model leisure choices for several reasons. First, reliable data on leisure hours in China is unavailable for multiple years. Secondly, based on the available data on work and home production hours, our estimates suggest that, over time, there was little change in the gender gap in leisure hours.
} 
male and female workers:

$$
\frac{w_{f}}{w_{m}}=\frac{\pi_{j} \chi_{j}}{1-\pi_{j} \chi_{j}}\left(\frac{L_{m j}}{L_{f j}}\right)^{\frac{1}{\eta}} .
$$

These wedges vary over time and thus capture changes in social norms and policies that either boost or reduce women's comparative advantage in a given sector.

\section{Model Predictions}

The model produces a set of predictions that we explore for the case of China. Firstly, given women's comparative advantage in the service sector, the model predicts that relative wages for women rise with an expansion of the service sector share in the process of structural transformation, as outlined in Proposition 1 in Ngai and Petrongolo (2017). Structural transformation across market sectors - reallocation of labor from goods to service sector - in turn, is driven by uneven sectoral productivity growth. Given that goods and services are complements, higher productivity growth in goods sector induces labor reallocation towards services. In Section 3.1, however, we document evidence of the contrary - while service sector share is rising, we see a decline in the relative female wages during the period between 1995 and 2013. The model allows us to pin down the role of the productivity wedge on female comparative advantage in reversing this relationship.

Secondly, the model predicts that faster growth of the market sectors compared to the home sector would lead to marketization of home-produced services. Given that market- and homeproduced services are substitutes, faster productivity growth of the market service sector increases the opportunity cost of producing services at home, inducing reallocation of labor to market sectors. As a result, the share of market services in total labor hours increases. This result also appears to be inconsistent with the stylized facts documented in Section 3.1, showing a decrease in both female and male LFP.

Finally, the model predicts that removal of sector-specific barriers to FLFP captures changes in female labor allocation not explained by productivity-driven mechanisms, including structural transformation and marketization of services. While the latter mechanisms explain between-sector reallocation of labor, changes in productivity wedges explain within-sector changes in female labor intensity.

\section{Calibration}

The model aims to account for changes in sectoral employment shares, female-to-male wage ratio, and gender-specific market and home production hours between 2000 and 2013. We calculate total work hours across market and home sectors, using sectoral employment data from the ILO, market hours from CHIP and home production hours from China's Health and Nutrition Survey (CHNS). ${ }^{13}$ For goods and service sectors, we first calculate average weekly hours for women and

\footnotetext{
${ }^{13}$ The China Health and Nutrition Survey (CHNS) is a project of Carolina Population Center at the University of North Carolina at Chapel Hill in collaboration with the National Institute for Nutrition and Health at the Chinese Center for Disease Control and Prevention. In addition to compiling information on households' health and nutrition behavior, the survey documents the time spent on various activities, similarly to the time use surveys. We use CHNS
} 
men and then scale them by the number of workers in each sector. Sectoral employment numbers are obtained from the ILO as in Section 3.1. For the home sector, we scale female and male average weekly hours spent on home production by the corresponding adult population, aged 15 to 64 . We use CHIP wage data to compute the gender wage gap. ${ }^{14}$

Table 4: Model Parameters

\begin{tabular}{lll}
\hline Parameter & Value & Source \\
\hline$\gamma_{g}-\gamma_{s}$ & 0.037 & World Bank, ILO, CHIP \\
$\gamma_{s}-\gamma_{h}$ & 0.041 & World Bank, ILO, CHIP, Bridgman et al. (2018) \\
$\sigma$ & 2.0 & Aguiar, Hurst, and Karabarbounis (2012) \\
$\epsilon$ & 0.002 & Herrendorf, Rogerson, and Valentinyi (2013) \\
$\eta$ & 2.27 & Ngai and Petrongolo (2017) \\
$\chi_{g}$ & 0.29 & Ngai and Petrongolo (2017) \\
$\chi_{s}$ & 0.43 & Ngai and Petrongolo (2017) \\
$L_{m} / L_{f}$ & 1.05 & Match service share in 2000, given male and female service and market hours \\
$\xi_{h}$ & 0.48 & Match wage and hours ratios in 2013 \\
\hline
\end{tabular}

We calculate labor productivity growth in goods and service sectors $\gamma_{g}$ and $\gamma_{s}$, using growth of sectoral value added per hour of work. Value added data is from the World Bank's World Development Indicators database and market hours described above are annualized to match the frequency of the value added data. We rely on Bridgman, Duernecker, and Herrendorf (2018) estimates of household value added per hour to estimate productivity growth in the home sector. Since household productivity estimates are not available for China, we use an average value of productivity growth rates between 2000 and 2013 of emerging countries and countries in the same region available in Bridgman, Duernecker, and Herrendorf (2018) dataset, including Taiwan, Korea, Japan, Mexico, Russia, and South Africa. Differences in sectoral productivity growth rates are presented in Table 4.

Elasticity parameters - $\sigma, \epsilon$, and $\eta$-are based on the existing estimates in the literature, as listed in Table $4 .^{15}$ Labor endowment ratio, $L_{m} / L_{f}$, is derived to match the service employment share in 2000, using data on male and female hours in the service sector and total market hours, as in Ngai and Petrongolo (2017).

We take female comparative advantage parameters, $\chi_{g}$ and $\chi_{s}$ from Ngai and Petrongolo (2017)

2000 waves as well as 2015 wave to interpolate 2013 value for women's and men's home production hours. Home production hours include time spent on childcare, cleaning, laundry, shopping, and food preparation. Average weekly hours spent on household activities reported in the CHNS are similar to those collected by the 2008 China Time Use Survey and time use surveys in other countries.

${ }^{14}$ Given that disaggregated sectoral employment data is available starting in 2000 from the ILO, we interpolate average sectoral weekly hours and wages from CHIP using 1995 and 2013 waves.

${ }^{15}$ The remaining elasticities, $\omega$ and $\psi$, are not needed as separate parameters (see Equations (23) and (30) in Ngai and Petrongolo (2017)). We match relative hours across goods and services to back out these expressions for the case of China. 
and back out the home comparative advantage parameter, $\xi_{h}$, by matching gender home hours ratio to the gender wage ratio in 2013. Based on these parameters, women have the highest comparative advantage in producing home services and the lowest in goods.

Table 5: Sector-specific Barriers to Female Employment

\begin{tabular}{lll}
\hline & 2000 & 2013 \\
\hline$\pi_{g}$ & 1.27 & 1.03 \\
$\pi_{s}$ & 0.86 & 0.70 \\
\hline
\end{tabular}

Notes: Female employment barriers are derived by matching changes in goods (market services) hours and wage ratios in 2000 and 2013.

We back out the productivity wedges, $\pi_{g}$ and $\pi_{s}$, by matching changes in sectoral hours ratios in response to the changes in the gender wage ratio from 2000 to 2013 . Given that comparative advantage parameters are calibrated based on the US data, we compare allocations of male and female labor in China in 2000 and 2013 to the case of the US in 2004-2008 (the latest year for which US estimates are available in Ngai and Petrongolo (2017)). Relative to the comparative advantage parameters suggested by the US data, the wedge between the wage ratio and the marginal rate of technical substitution in the goods sector is smaller in China (Table 5), i.e., we observe relatively more women in the goods sector in China compared to the US. However, the results suggest that, over time, productivity wedges widened in the service sector and women's participation in the goods sector converged to that of the US. These findings show that barriers to female workers' entry into both goods and service sectors increased by a third in a span of only 13 years. Despite a growing in the service sector share, which is generally associated with narrowing gender wage and market hours gaps, we see that increasing barriers to female employment in both service and goods sectors are reversing this fundamental relationship in the structural transformation context. Below we explore various factors that may have contributed to increasing barriers to female employment in China. We also perform a set of counterfactual exercises to quantify gains in female employment, wages, and the aggregate economy from removing these barriers.

\section{Model Implications and Policy Discussion}

This section performs the counterfactual exercises in the context of the model presented in Section 4, and describes a set of China's institutional characteristics driving the productivity wedges. The counterfactual exercises aim to quantify the effect of gender-biased policies on female wages, LFP, and economic growth. We link the counterfactual analysis to potential policies aimed at addressing gender inequality in China. 


\subsection{Policy Dimensions of Gender Gaps}

This section discusses the prevailing policy environment that distorts the playing field for women in China.

Figure 4: International Comparison of Women, Business, and Law Index

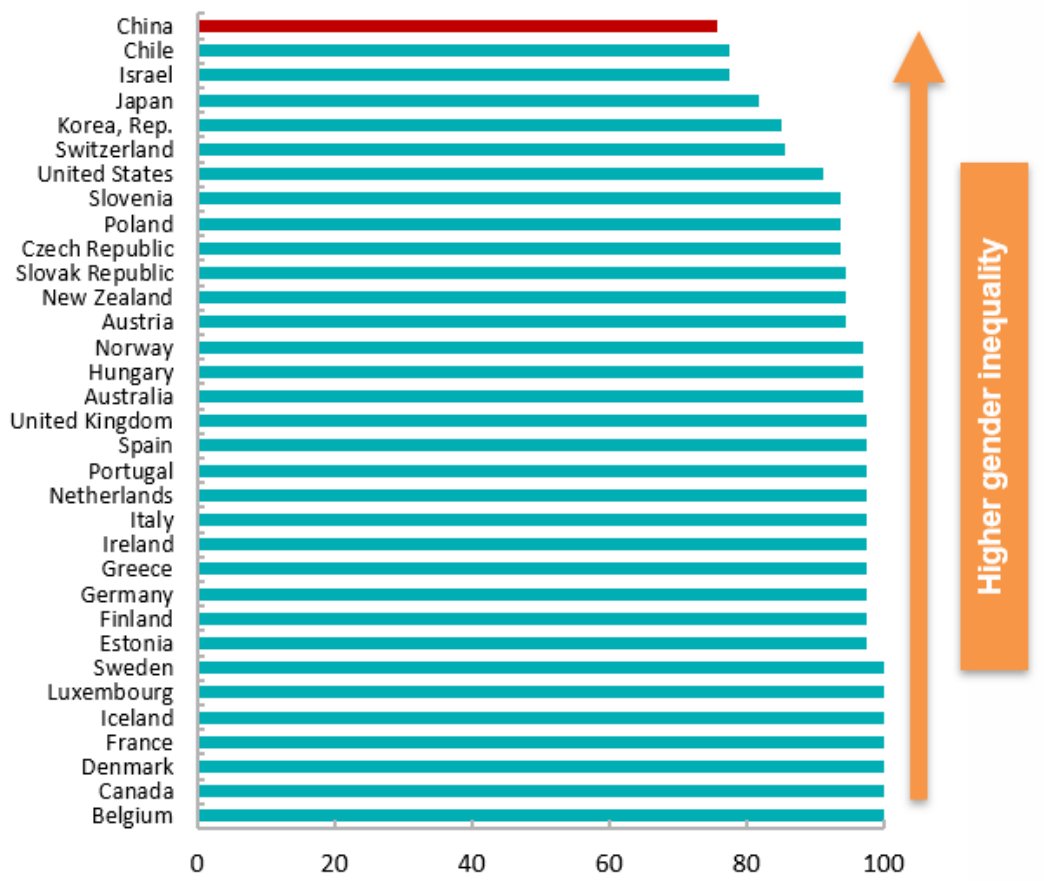

Source: World Bank, and staff calculations.

Existing evidence from cross-country comparisons suggests persistent gender gaps in China across a range of socio-economic indicators. Figure 4 presents the aggregate scores on the Women, Business and the Law index which measures differences in laws and regulations that restrict women's economic opportunities. ${ }^{16}$ As can be seen from the figure, China falls behind the advanced and emerging economy average in providing economic opportunities for women. Similarly, the OECD Social Institutions and Gender Index (SIGI index) shown in Figure 5 also ranks China the highest on gender biases against women among selected countries. ${ }^{17}$

Fundamental gender bias may exist due to cultural and historical reasons, leading to limited decision-making power by women, undervalued status in the household and family decision planning, and a high son bias. While such cultural and historical biases can take a long time to dissipate, there are a number of areas where gender-biased policies can be implemented such as availability of affordable childcare, adopting family-friendly leave policies, removing gender-based hiring biases, and support for women's entrepreneurship to close existing gaps. ${ }^{18}$

\footnotetext{
${ }^{16}$ The World Bank compiles the Women, Business and the Law (World Bank, 2021) dataset for 190 economies.

${ }^{17}$ The OECD SIGI index (Branisa, Klasen, and Ziegler, 2009) dataset measures discrimination against women in social institutions across 180 countries, taking into account laws, social norms and practices.

${ }^{18}$ In addition to the social and policy dimensions discussed in this section, we examined existing evidence on the
} 
Figure 5: International Comparison of Social Institutions and Gender Index

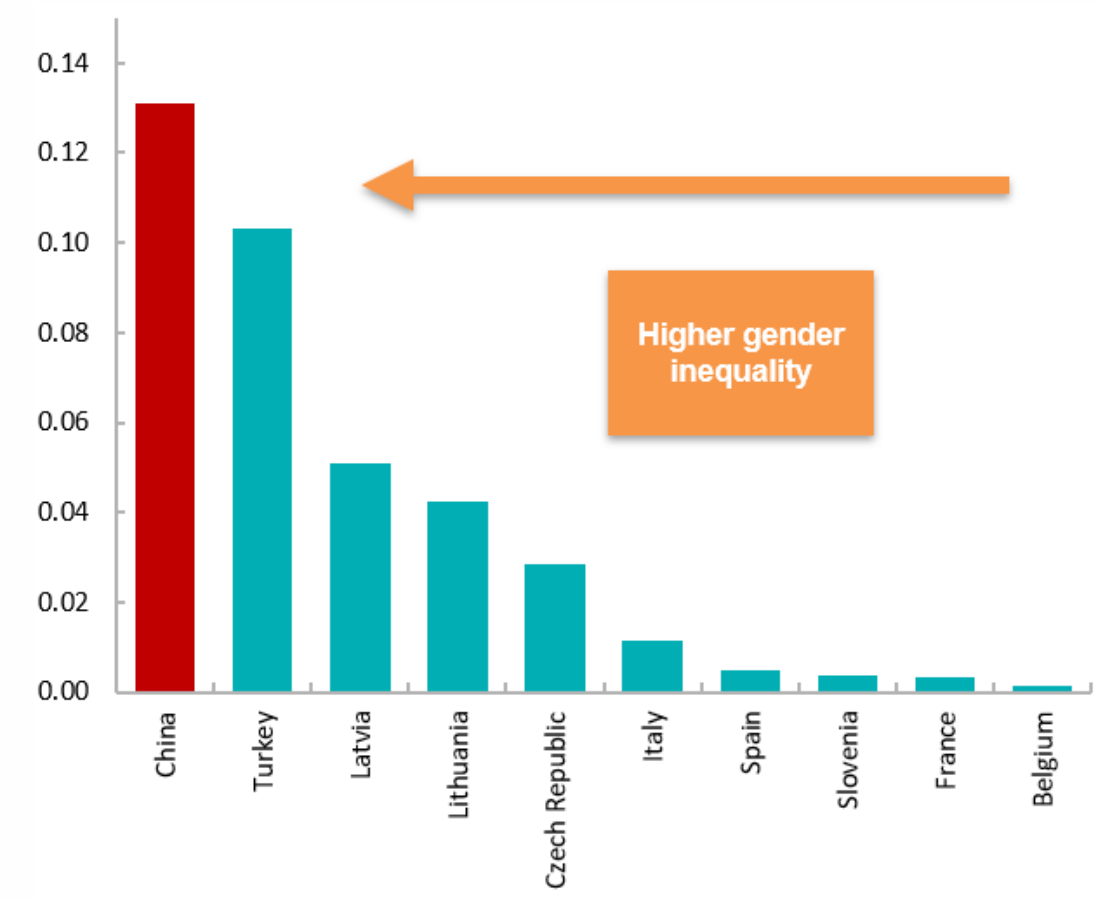

Source: OECD, and staff calculations.

\section{Ensuring Affordable Childcare and Family-friendly Policies}

Connelly, Dong, Jacobsen, and Zhao (2018) report that childcare support from the state has declined in recent decades, with the result that Chinese women spend more time at home taking care of their children, limiting their ability to participate fully in the labor force. In addition, the care burden can lead women to concentrate in low-paid, informal, or home-based work as a means of balancing unpaid care work and paid employment, contributing to gender wage gaps. Childcare cost have also been rising faster than incomes in China (Qin, 2019), with many lower-income families facing relatively high childcare costs in relation to their earnings. For instance, nursery fees have risen to around 15-20 percent of a middle-class family's annual income. Rising childcare costs not only intensify the shrinking of China's workforce, but also impose challenges for labor market participation by married women. ${ }^{19}$

Reducing the cost of childcare is crucial for working mothers with preschool children to increase their LFP. Care policies can range from direct provision of care services and care-related infrastructure to public subsidies, tax credits, and care credits that potentially expand the supply of child

role of tax wedges on gender inequality in China. A recent study by Organisation for Economic Co-operation and Development (2020) compares tax wedges for a one-earner married couple with two children and the corresponding single worker without children. The study does not find evidence of a tax wedge between the two household types in China.

${ }^{19}$ Despite China's controversial one-child policy being repealed in 2015, the number of new births in China has been falling in recent years. In 2018 alone, the new births fell by 2 million to 15.2 million. More than half of married couples delay having children because of high childcare costs (Qin, 2019). 
and dependent care and increase its affordability. Evidence suggests that subsidizing child and elderly care costs for working mothers increases the marginal returns from participation in the paid workforce. When women participate in the labor market, they accumulate returns on experience, which also increases their income over their life cycle.

Parental leave policies can also be an important instrument for supporting work-life balance in China. For instance, Blau and Kahn (2013) show that parental leave had positive effects on FLFP in OECD countries. Allowing families to share parental leave could help alleviate some of the pressure on women at home and at work. However, where a mother has lower earnings than her partner, there can still be a strong incentive for fathers to continue working. As a result, many OECD countries are reserving non-transferable periods of paid parental leave exclusively for use by fathers. This approach has the advantage that if a father decides to take leave it does not affect his partner's entitlement. Mandating minimum nationwide paternity leave and encouraging uptake by male workers could be considered.

Flexibility and part-time leave arrangements can also be beneficial as they minimize the financial impact of taking leave, while allowing employees to remain connected to their jobs and to care for children (Adema, Clarke, and Frey, 2015). Speeding up digitalization of work and providing relevant training, with a particular emphasis on closing the gender divide in access to digital tools, can foster flexibility of work arragments and boost FLFP.

\section{Enforcing Legal Regulations and Reducing Gender Bias at Work}

Legal institutions and regulations should aim to eliminate discriminatory practices and provide a level playing field. Although Chinese law prohibits gender discrimination in hiring, Zhang and Huang (2020) note that gender-based hiring biases have been on the rise. For instance, job advertisements often explicitly state preferences for men over women. Similarly, while Chinese law explicitly prohibits discrimination against pregnant women and mothers with young children, practices usually fall short, and women often face a motherhood penalty, making a return to work more challenging. Removing discriminatory hiring, firing, and promotion practices, linked to fertility decisions can produce more equal opportunities for career progression. This is particularly relevant following the removal of the one-child policy in 2015, as more women choose to have larger families.

Workplace discrimination is also reflected in female representation in professional and managerial jobs. As shown in Wang and Klugman (2020), women's share in management was still one of four in 2010 and remains much lower than in emerging economies as Brazil (36 percent) and Mexico (31 percent), and other advanced economies (about half in the United States and United Kingdom). Gender leadership gaps can also reflect distortions in the pension system which imposes different retirement ages by gender and leaves less time for women to climb through the ranks. Removing barriers to women continuing to work past the age of 50 and 55 (in blue-collar and white-collar work, respectively), and aligning with male retirement age of 60, can help enforce equal treatment of women in the workplace.

\section{Support for Women's Entrepreneurship}


Although entrepreneurial activity doubled over a decade following China's accession to the WTO in 2001 (Hernandez, Nunn, and Warnecke, 2012), women's entrepreneurial activity has lagged far behind men. China also has relatively fewer female entrepreneurs overall as a proportion of the adult working-age population (aged 18 to 64) than other OECD countries (Woetzel, Madgavkar, Sneader, Tonby, Lin, Lydon, and Gubieski, 2018). Although Chinese law does not prohibit discrimination in access to credit based on gender, a range of social and institutional barriers impede access to finance. Traditional assessments of credit risk rely on land ownership, credit history, and availability of collateral, disproportionately disadvantaging women. Strengthening implementation of laws to prohibit gender discrimination in access to credit market and ensuring availability of formal financing for women, including through the use of technology, and targeting funding toward womenled initiatives, can support entrepreneurial activities by women.

\subsection{Model Counterfactuals and Results}

We perform two counterfactual exercises using the model described in Section 4 and quantify the potential effect of policies discussed above on gender inequality. In the first counterfactual exercise, we examine the impact of policies aimed at eliminating barriers for women to participate in the labor market, such as policies to support female entrepreneurship, strengthen child and elderly care provision, and eliminate gender bias in the workforce. In the second exercise, we quantify the impact of faster marketization of services. Faster productivity growth of the market service sector that results in a reallocation of service production from home to the market can be achieved by investing in childcare and elderly care, strengthening social safety nets, and deregulation of the service sector.

\section{Counterfactual 1: Removing Productivity Wedges}

The first counterfactual exercise aims to partially remove sector-specific productivity wedges, $\pi_{g}$ and $\pi_{s}$, documented in Table 5 . Eliminating wedges that lower women's perceived marginal product of labor relative to that of men would, in turn, increase within-sector demand for female labor. We take the US in 2004-2008 as the benchmark, given that the comparative advantage parameters, $\chi_{g}$ and $\chi_{s}$, are borrowed from Ngai and Petrongolo (2017). By setting $\pi_{g}$ and $\pi_{s}$ to unity, we assume that the level of labor market bias in China is similar to that in the US in 2004-2008 period. All other parameters of the model remain unchanged. Our estimates in Table 5 suggest that within-sector gender inequality in China in 2000 more closely resembled the US in 2004-2008 than China's 2013 labor market outcomes. Therefore, this exercise does not assume complete removal of within-sector gender biases, given that gender inequality in both wages and employment were also present in the US.

Table 6 shows that the model closely matches both the unconditional gender wage gap and market hours gaps in 2000 and 2013 observed in the data. Data suggests that women's earnings decline from about 84 percent in 2000 to 65 percent of men's wages in 2013, while relative market 
hours drop from 47 percent to about 41 percent of men's hours. ${ }^{20}$ The first set of counterfactual results $\left(\pi_{g}=\pi_{s}=1\right)$, suggests that removal of labor market barriers in both goods and service sectors would result in substantial narrowing of both gender gaps. Matching the comparative advantage parameters to those of the US, China's unconditional wage gap would be reduced from about 40 percent to about 22 percent. Female employment gains would be substantially higher-reduction of labor market barriers would result in a reduction in the market hours gap by almost 32 percentage points.

Table 6: Counterfactual Results

\begin{tabular}{lcccc}
\hline & \multicolumn{2}{c}{ Wage Gap } & \multicolumn{2}{c}{ Market Hours Gap } \\
& 2000 & 2013 & 2000 & 2013 \\
\hline Data & 84.4 & 64.9 & 46.6 & 41.3 \\
Model Baseline & 84.4 & 69.1 & 46.6 & 35.9 \\
Counterfactual 1: $\pi_{g}^{\star}=\pi_{s}^{\star}=1$ & \multicolumn{2}{c}{77.9} & & \multicolumn{2}{c}{72.8} \\
Counterfactual 2: $\pi_{g}^{\star}=\pi_{s}^{\star}=1$ and $\gamma_{s}^{\star}>\gamma_{s}$ & \multicolumn{2}{c}{78.1} & \multicolumn{2}{c}{77.7} \\
\hline
\end{tabular}

Source: CHIP, CHNS, ILO, World Bank, and staff calculations

\section{Counterfactual 2: Accelerating Marketization of Services}

Increasing the relative productivity growth of the market sectors by 50 percent would result in additional gains in both women's relative wages and hours. We set the difference between market and home services productivity growth rates $\left(\gamma_{s}-\gamma_{h}\right)$ to 6.2 percentage points compared to 4.1 percentage points in the baseline, while keeping the relationship between market services and goods productivity rates unchanged. Faster marketization has a relatively small additional effect on the gender wage ratio. However, it results in 5 percentage points decline in the gender market hours gap, as women exit home production and enter the market sector (Table 6). These results suggest that reforms boosting overall productivity of the market sector and rebalancing towards a more robust service sector could have an sizeable positive effect on gender equality in China. In addition, we find that narrowing gender gaps in hours and wages to the levels described in Table 6 would result in 4.9 percent higher output.

\section{Conclusion}

This paper investigates the drivers of widening gender gaps in employment and earnings in China. We document that FLFP and earnings gaps have widened in recent decades while narrowing in many other parts of the world. This trend runs counter to the predictions of the standard structural transformation literature as the share of market services, where women reveal a comparative advantage, has increased significantly in China. Both economic (e.g., the income effect) and policy drivers underpin widening gender gaps in the labor market. Our model-based analysis suggests that

\footnotetext{
${ }^{20}$ We use conditional earnings gaps reflected in Table 1.
} 
removing barriers to FLFP, accelerating the marketization process, and increasing productivity in the market service sector would reduce gender inequality and boost economic growth.

These findings are especially pertinent for China going forward, as the legacy of the one-child policy unfolds. With rapid aging of Chinese population, the burden of elderly care is likely to disproportionately fall on women and further exacerbate gender inequality and women's ability to productively participate in the labor market. Increasing FLFP can also help boost output and productivity in the face of an aging and shrinking population.

There is considerable scope for policies to reduce gender inequality in the labor market. This includes removing discriminatory practices against women in the workforce and in pay to level the playing field. The availability of low cost, high quality child and elderly care would lift the burden on women seeking employment and on firms that would have to pay a premium to hire women. Easing regulations and entry barriers to boost productivity in the service sector would also have a knock on effects on reducing gender gaps, while supporting the economy. 


\section{References}

Adema, Willem, Chris Clarke, and Valérie Frey (2015): "Paid parental leave: Lessons from OECD countries and selected US states," Discussion paper, Organisation for Economic Co-operation and Development.

Aguiar, Mark, Erik Hurst, and Loukas Karabarbounis (2012): "Recent developments in the economics of time use," Annual Review of Economics, 4(1), 373-397.

Akbulut, Rahşan (2011): "Sectoral changes and the increase in women's labor force participation," Macroeconomic Dynamics, 15(2), 240-264.

Alon, Titan, Matthias Doepke, Jane Slmstead-Rumsey, and Michele Tertilt (2020): "The impact of COVID-19 on gender equality," Discussion paper, National Bureau of Economic Research.

Blau, Francine D, and Lawrence M Kahn (2007): "Changes in the labor supply behavior of married women: 1980-2000," Journal of Labor economics, 25(3), 393-438.

- (2013): "Female labor supply: Why is the United States falling behind?," American Economic Review, 103(3), 251-56.

Bluedorn, John, Francesca Caselli, Niels-Jakob Hansen, Ippei Shibata, and Marina M. Tavares (2021): "Gender and Employment in the COVID-19 Recession: Evidence on "She-cessions"," Discussion Paper IMF WP, International Monetary Fund.

Branisa, Boris, Stephan Klasen, and Maria Ziegler (2009): "The construction of the social institutions and gender index (SIGI)," Discussion paper, IAI Discussion Papers.

Bridgman, Benjamin, Georg Duernecker, and Berthold Herrendorf (2018): "Structural transformation, marketization, and household production around the world," Journal of Development Economics, 133, 102-126.

Chen, Xi, and Suqin Ge (2018): "Social norms and female labor force participation in urban China," Journal of Comparative Economics, 46(4), 966-987.

Connelly, Rachel, Xiao-yuan Dong, Joyce Jacobsen, and Yaohui Zhao (2018): "The care economy in post-reform China: feminist research on unpaid and paid work and well-being," Feminist Economics, 24(2).

Dang, Hai-Anh H, and Cuong Viet Nguyen (2021): "Gender inequality during the COVID-19 pandemic: Income, expenditure, savings, and job loss," World Development, 140, 105296.

Dasgupta, Sukti, Makiko Matsumoto, and Cuntao Xia (2015): "Women in the labour market in China," Discussion paper, ILO Bangkok.

Dong, Xiao-Yuan, and Veronica Mendizabal Joffre (2019): "Inclusive Growth in the People's Republic of China: A Deep Look at Men and Women's Work Amid Demographic, Technological, and Structural Transformations," Discussion paper, Asian Development Bank.

Feng, Shuaizhang, Yingyao Hu, and Robert Moffitt (2017): "Long run trends in unemployment and labor force participation in urban China," Journal of Comparative Economics, 45(2), 304-324.

Goldin, Claudia (1994): "The U-shaped female labor force function in economic development and economic history," Discussion paper, National Bureau of Economic Research.

Greenwood, Jeremy, Nezih Guner, Georgi Kocharkov, and Cezar Santos (2014): "Marry your like: 
Assortative mating and income inequality," American Economic Review Papers and Proceedings, 104(5), 348-53.

Han, Jun, Runjuan Liu, and Junsen Zhang (2012): "Globalization and wage inequality: Evidence from urban China," Journal of International Economics, 87(2), 288-297.

Heckman, James J (1979): "Sample selection bias as a specification error," Econometrica, pp. $153-161$.

Heim, Bradley T (2007): "The incredible shrinking elasticities married female labor supply, 19782002," Journal of Human Resources, 42(4), 881-918.

Hernandez, Lucas, Nicholas Nunn, and Tonia Warnecke (2012): "Female entrepreneurship in China: opportunity-or necessity-based?," International Journal of Entrepreneurship and Small Business, 15(4), 411-434.

Herrendorf, Berthold, Richard Rogerson, and Akos Valentinyi (2013): "Two perspectives on preferences and structural transformation," American Economic Review, 103(7), 2752-89.

- (2014): "Growth and structural transformation," in Handbook of economic growth, vol. 2. Elsevier.

Jayachandran, Seema (2020): "Social norms as a barrier to women's employment in developing countries," Discussion paper, National Bureau of Economic Research.

Li, Bin Grace, Prakash Loungani, and Jonathan D. Ostry (2017): "Trade, Growth and Inequality: Evidence from China," Discussion paper, International Monetary Fund.

Li, Haizheng, and Jeffrey S Zax (2003): "Labor supply in urban China," Journal of Comparative Economics, 31(4), 795-817.

Liu, Bohong, Ling Li, and Chunyu Yang (2014): "Gender equality in China's economic transformation," Discussion paper, United Nations.

Mammen, Kristin, and Christina Paxson (2000): "Women's work and economic development," Journal of Economic Perspectives, 14(4), 141-164.

Mroz, Thomas A (1987): "The sensitivity of an empirical model of married women's hours of work to economic and statistical assumptions," Econometrica, pp. 765-799.

Nabar, Mr Malhar, and Mr Kai Yan (2013): "Sector-level productivity, structural change, and rebalancing in china," Discussion Paper IMF WP 13/240, International Monetary Fund.

Ngai, L Rachel, and Barbara Petrongolo (2017): "Gender gaps and the rise of the service economy," American Economic Journal: Macroeconomics, 9(4), 1-44.

Olivetti, Claudia (2013): "The female labor force and long-run development: the American experience in comparative perspective," Discussion paper, National Bureau of Economic Research.

Olivetti, Claudia, and Barbara Petrongolo (2016): "The evolution of gender gaps in industrialized countries," Annual Review of Economics, 8, 405-434.

Organisation for Economic Co-operation and Development (2020): "Taxing Wages in selected partner economies: Brazil, China, India, Indonesia and South Africa in 2018," Discussion paper, Organisation for Economic Co-operation and Development.

Ostry, Jonathan D., Jorge Alvarez, Raphael A. Espinoza, and Chris Papageorgiou (2018): "Eco- 
nomic gains from gender inclusion: New mechanisms, new evidence," Discussion paper, International Monetary Fund.

Qin, A (2019): “A prosperous China says 'men preferred,' and women lose," The New York Times, July, 16, 2019.

Rendall, Michelle (2013): "Structural change in developing countries: has it decreased gender inequality?," World Development, 45, 1-16.

- (2018): "Female market work, tax regimes, and the rise of the service sector," Review of Economic Dynamics, 28, 269-289.

Sinha, Jania N (1965): "Dynamics of female participation in economic activity in a developing economy," in World population conference, Belgrade, vol. 4.

Wang, Limin, and Jeni Klugman (2020): "How women have fared in the labour market with China's rise as a global economic power," Asia 86 the Pacific Policy Studies, 7(1), 43-64.

Woetzel, Jonathan, Anu Madgavkar, Ke Sneader, O Tonby, DY Lin, J Lydon, and M Gubieski (2018): "The power of parity: advancing women's equality in Asia pacific," Discussion paper, The McKinsey Global Institute.

World Bank (2021): "Women, Business, and the Law," Discussion paper, World Bank.

World Economic Forum (2019): "Mind the 100 Year Gap," Discussion paper, World Economic Forum.

Zhang, Eva Yiwen, and Tianlei Huang (2020): "Gender discrimination at work is dragging China's growth," Discussion paper, Peterson Institute for International Economics.

Zhu, Min, Longmei Zhang, and Daoju Peng (2019): "China's Productivity Convergence and Growth Potential-A Stocktaking and Sectoral Approach," Discussion Paper IMF WP 19/263, International Monetary Fund. 